Original Russian Text (C) 2020 E.V. Ruchinskaya, A.V. Gornov published in Forest Science Issues Vol. 3, No. 4, pp. 1-25

DOI 10.31509/2658-607x-202141a19

\title{
INFLUENCE OF SINGLE TREES ON FLORISTIC DIVERSITY OF STEPPE MEADOWS AND POPULATION STRUCTURE OF SOME RARE PLANT SPECIES
}

\author{
E.V. Ruchinskaya*, A.V. Gornov \\ Center for Forest Ecology and Productivity of the Russian Academy of Sciences \\ Profsoyuznaya st. 84/32 bldg. 14, Moscow 117997, Russian Federation \\ *E-mail: elena.ruchinskaya@mail.com
}

Received 01.11.2020

Accepted 14.12.2020

In the zone of broad-leaved forests of the European Russia, steppe meadows have been preserved showing rich floristic composition and making a significant contribution to the biological diversity of the territories. Bryansk oblast is one of the forest regions in Russia where such meadows are found. Here, steppe meadows with high floristic diversity and a large number of rare plant species have survived. Trees from surrounding forest areas are constantly encroaching on these meadows. Most of the young trees die from regular grass fires and economic activity. However, some individuals survive and reach a generative state, becoming relatively resistant to ground fires. The influence of single trees on the floristic diversity of steppe meadows was studied at two levels of living system organization - coenotic and population levels. Polydominant steppe meadows and polydominant steppe meadows with single generative trees were studied at the coenotic level; and coenopopulations of Iris aphylla, Anemone sylvestris, and Anthericum ramosum were studied at the population level. Collecting the material, we used different methods: geobotanical, demographic, and measurements of environmental factors (illumination, slope steepness, and the frequency of grass fires). Polydominant steppe meadows were found to be were preserved in the middle part of steep slopes unsuitable for haymaking and grazing and subjected to infrequent grass fires. These communities have high floristic diversity and stable coenopopulations of model species. Ontogenetic spectra of Anemone sylvestris, Anthericum ramosum, and Iris aphylla are of the complete left-hand type with the maximum number of individuals. Single trees (Quercus robur, Tilia cordata) have controversial influence on the vegetation of polydominant steppe meadows. On the one hand, with the introduction of trees, species diversity of communities increases. This is due to the fact that trees offer resting places and shelter for birds that spread plant diaspores. On the other hand, mature trees shade the herb cover. This leads to cover reduction and occurrence of steppe and dry meadow species, as well as affects their population structure. The ontogenetic spectrum of Anemone sylvestris is still complete, whereas that of Iris aphylla becomes incomplete, and the spectrum of Anthericum ramosum becomes unfinished.

Key words: steppe meadow, single trees, floristic diversity, coenopopulations, ontogenetic spectrum, state of coenopopulations, Anemone sylvestris, Anthericum ramosum, Iris aphylla

Steppe meadows have survived in the zone of broad-leaved forests of the European Russia (Bulohov, 1977, 2001; Bosek, 1980; Skvorcov, 1982; Averinova, 2010; Semenishhenkov, 2010, 2012; Evstigneev et al., 2011; Panasenko et al., 2013, 2015, etc.). These communities, in general, have rich floristic composition and make a significant contribution to the biological diversity of the territories. However, due to human economic 
activity and grass fires, such coenoses are in danger of extinction (Zelenaja ..., 2012; Evstigneev et al., 2018a; Ruchinskaya, 2019). Woody plants from the surrounding forest areas are constantly encroaching on the steppe meadows preserved in the zone of broadleaved forests. Most of the young trees die from regular grass fires and economic activities such as haymaking, grazing, etc. However, some individuals survive and go into a generative state (Evstigneev et al., 2018a). Mature trees are relatively resistant to ground fires: their renewal buds are located high and the thick crust of the trunk protects the cambium (Serebrjakov, 1962). Single trees affect the growing conditions of other plants in the meadows. It is known that in phytogeneous fields of trees, illumination, air temperature and humidity, soil temperature and humidity, the amount of precipitation penetrating through the crown, quality of litter, concentration of nutrients and other soil characteristics change significantly (Uranov, 1965; Samojlov, 1983; Nikonov et al., 2002; Ipatov, 2007; Zhuravleva et al., 2012; Orlova et al., 2016). In addition, single trees attract animals of different ecological groups, e.g. soil invertebrates, mouse-like rodents, birds, etc. (Manning et al., 2006; Prevedello et al., 2018). On the one hand, these influence the growing conditions of plants, and on the other hand, they participate in the creation of both intracoenotic and intercoenotic flows of diaspores. Therefore, the objective of this work is to consider the influence of single trees on the floristic composition and the state of coenopopulations of some rare plant species in the steppe meadows.

\section{MATERIAL AND METHODS}

The research was carried out in the southeast of Bryansk oblast within the Melovitskie Slopes natural monument (Figure 1). The site is located in Komarichsky-Sevsky physiographic region. It consists of elevated loess plains with ravines, gullies, slopes and outcrops of carbonate rocks on the western offsets of the Central Russian Upland. Botanically and geographically, the territory belongs to the Eastern European Province of the European broad-leaved forest region (Rastitel'nost'..., 1980). Komarichsky-Sevsky district has temperate continental climate. The mean annual temperature is $5.4 \mathrm{C}$. The duration of the warm season with abovefreezing temperatures is 228 days; the growing season with the temperature above + $5^{\circ} \mathrm{C}$ is 188 days. Mean annual precipitation is $613 \mathrm{~mm}$; the mean precipitation in the warm season is $342 \mathrm{~mm}$ (Prirodnoe ..., 1975).

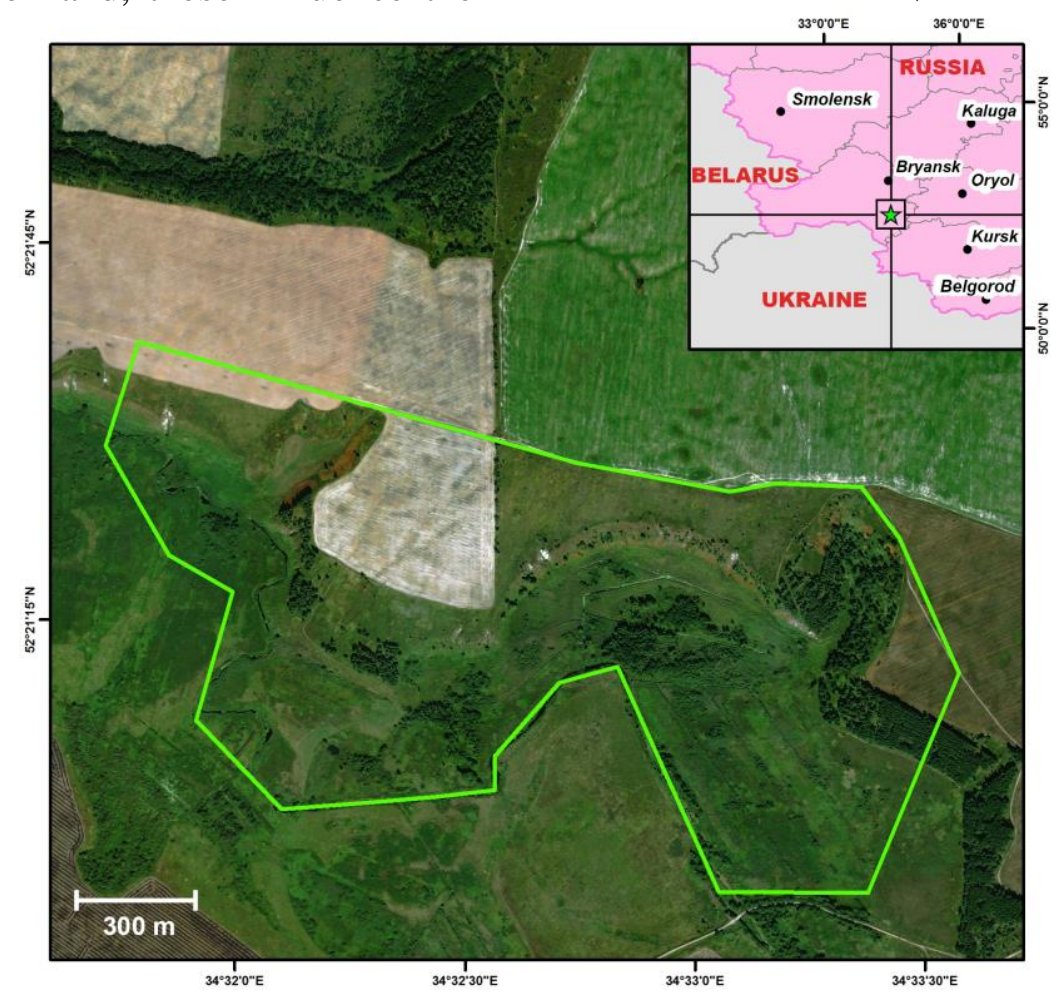

Figure 1. Location of the Melovitskie Slopes natural monument. The green line represents the boundaries of the research object. Background satellite imagery by Microsoft Bing Maps 
The research was carried out at two levels of living system organization, i.e. at the coenotic and population level. Polydominant steppe meadows and polydominant steppe meadows with single generative trees were studied at the coenotic level. At the population level, the objects of the study were coenopopulations of model plant species Iris aphylla L., Anemone sylvestris L., and Anthericum ramosum L. Iris aphylla is a short rhizome rosette spring-flowering summergreen plant (Figure 2, A). It is a geophyte. Anemone sylvestris is a perennial herbaceous spring-flowering summer-green short rhizome plant (Figure 2, B). It is a hemicryptophyte and geophyte. Anthericum ramosum is a perennial herbaceous summer-green summerflowering short rhizome plant (Figure 3). It is a hemicryptophyte and geophyte. These species were chosen due to the fact that they are rare, endangered and listed in Red Books of many regions (Krasnaja..., 2002, 2004, 2015, 2016, etc.). Moreover, Iris aphylla is listed in the Red Book of Russia (2008).

The following research methods were used: geobotanical, demographic, statistical, and measurements of habitat factors. Relevés were made on plots of $100 \mathrm{~m}^{2}$ in 11-fold repetition for each community type. A complete floristic list was compiled at each plot. Species participation was evaluated as scores according to the cover-abundance scale proposed by J. Braun-Blanquet (Mirkin et al., 1989). Species richness and species density were used to assess the species diversity of communities. Species richness is the total number of species in a community, which is obtained on the basis of 11 relevés. Species density is the average number of species per unit area. The names of vascular plants were given according to The Plant List international database (http://www.theplantlist.org/). For relevé analysis of communities, ordination was carried out using Detrended Correspondence Analysis (DCA). This method works successfully with heterogeneous data of relevés (Dzhongman et al., 1999). PC-ORD software was used for calculations. Demographic research was based on ontogenesis periodization proposed by T.A. Rabotnov (1950) and supplemented by A.A. Uranov (1975) and other scientists
(Cenopopuljacii ..., 1988). Ontogenesis is divided into stages that show morphological and functional differences. Individuals belonging to the same ontogenetic state are grouped together: $j$-juvenile, im - immature, $v$ - virginile, $g_{1}$ - young generative, $g_{2}-$ mature generative, $g_{3}$ - old generative, $s s-$ sub-senile, $s$ - senile. Ontogenetic states of the model species were determined on the basis of publications (Evstigneev et al., 2018; Ruchinskaya, 2019). The state of coenopopulations was estimated using the number, density, and type of the ontogenetic spectrum. Number is the number of individuals in the study area (Chernova, Bylova, 2007). Population density is the average number of individuals per unit area (Odum, 1986; Cenopopuljacii ..., 1988). The type of the ontogenetic spectrum was named according to the classification proposed earlier (Zaugol'nova, 1994b). In the meadows and under the trees, the illuminance was measured hourly with a light meter on a cloudless June day from 10 a.m. to 6 p.m. Illuminance in lux was converted to a percentage of the total illuminance, which was measured in the open space. The slope steepness was measured using a Nikon Forestry Pro rangefinder. The frequency of grass fires was determined by the age of shoots of formation in shrubs (Frangula alnus Mill., Corylus avellana L.). These shoots emerge from dormant buds located in the basal part of the shrub. The former aboveground shoots were destroyed due to fire damage (Figure 4).

\section{RESULTS AND DISCUSSION}

Polydominant steppe meadows were preserved in the middle part of steep slopes hardly suitable for haymaking and grazing (Figure 5). Grass fires mainly occur once every two years. They limit the introduction of woody plants as young tree species are most vulnerable. For instance, seedlings and juvenile oak plants often die during grass fires (Komarov, 1951). As a result, polydominant communities with high species diversity are formed (Table 1; Suppl. materials). These coenoses are unique since they include species that are characteristic of steppe communities: Ajuga genevensis L., Anemone sylvestris, Aster amellus L., Astragalus cicer 
L., Campanula sibirica L., Prunus cerasus L., Galium tinctorium L., G. verum L. etc. The ecological-coenotic structure is dominated by plants of the dry meadow group, which also includes the above-named steppe plants. Moist meadow (Festuca pratensis Huds., Hypericum maculatum Crantz, Succisa pratensis Moench, Thalictrum lucidum L. и др.), nemoral forest-edge (Brachypodium pinnatum (L.) Beauv., Peucedanum cervaria (L.) Cusson ex Lapeyr, Laserpitium latifolium L., Lathyrus pisiformis L., L. sylvestris L., Pyrethrum corymbosum (L.) Scop.), and nitrophilous forest-edge (Rubus caesius L. and Valeriana officinalis L.) plants are often found as well. Small participation is typical of forest species, i. e. nemoral - Convallaria majalis L., Corylus avellana, Quercus robur L., Viola mirabilis L., boreal - Frangula alnus, and piny - Pteridium aquilinum, Solidago virgaurea L., and Viola collina Besser. Diaspores of forest and forest-edge species are brought here by animals and wind from the neighbouring pine forest. Moist meadow and nitrophilous species are brought from floodplain communities adjacent to the slope.

Table 1. Characteristics of communities on the steppe slopes. Melovitskie Slopes natural monument

\begin{tabular}{|c|c|c|}
\hline \multirow{2}{*}{ Indicators } & \multicolumn{2}{|c|}{ Communities } \\
\hline & 1 & 2 \\
\hline \multicolumn{3}{|c|}{ Slope angle } \\
\hline Slope angle, $M \pm \sigma$ & $37 \pm 2.4$ & $31 \pm 2.4$ \\
\hline Slope angle range & $33-41$ & $28-37$ \\
\hline Number of measurements & 21 & 33 \\
\hline \multicolumn{3}{|c|}{ Fires } \\
\hline Fire frequency, $M \pm \sigma$ & $2.3 \pm 1.2$ & $2.2 \pm 1.0$ \\
\hline Number of measurements & 52 & 33 \\
\hline \multicolumn{3}{|c|}{ Characteristics of the diversity of vascular plant species } \\
\hline Average number of species per $100 \mathrm{~m}^{2}, M \pm m_{M}$ & $51 \pm 1.2$ & $59 \pm 1.2$ \\
\hline Range of number of species per $100 \mathrm{~m}^{2}$ & $44-56$ & $52-66$ \\
\hline Number of species on 11 plots of $100 \mathrm{~m}^{2}$ each & 98 & 107 \\
\hline \multicolumn{3}{|c|}{ Number and proportion (\%) of species of different ecological-coenotic groups } \\
\hline Dry meadow & $77(78.6)$ & $79(73.8)$ \\
\hline Moist meadow & $5(5.1)$ & $7(6.5)$ \\
\hline Nemoral forest & $4(4.1)$ & $8(7.5)$ \\
\hline Nemoral forest-edge & $6(6.1)$ & $6(5.6)$ \\
\hline Piny & $3(3.1)$ & $3(2.8)$ \\
\hline Boreal forest & $1(1.0)$ & $1(1.0)$ \\
\hline Nitrophilous forest-edge & $2(2.0)$ & $3(2.8)$ \\
\hline
\end{tabular}

Note. $M$ is the arithmetic mean, and $\sigma$ is the standard deviation. Communities: 1 - polydominant steppe meadows, 2 - polydominant steppe meadows with single generative trees

Iris aphylla is one of the predominant species in the herb layer of polydominant steppe meadows of the Melovitskie Slopes. Population density of Iris aphylla is 82 plants per $1 \mathrm{~m}^{2}$. The ontogenetic spectrum is complete single-peak with a maximum at $v$ and $g_{H}$ plants (Figure 6, 1a). Iris aphylla is well adapted to high illuminance of open spaces due to the structure of its leaves: they are flattened laterally and vertically oriented (Evstigneev et al., 2018b). Seed renewal of Iris aphylla is facilitated by the activity of animals such as ants and mouse-like rodents that inhabit the slopes and create disturbances. These microsites are characterized by sparse herb cover, loosened substrate, increased aeration and soil temperature, and significant microbiological activity (Zrjanin, 2003; Dauber, Wolters, 2000; Kostrakiewicz, 2004, etc.). For example, a population locus consisting of 10 juvenile plants was found in a $0.03 \mathrm{~m}^{2}$ earth ejections of the mouse-like rodent. The spread of Iris aphylla diaspores is facilitated by ants (Figure 7). R.E. Levina 
(1957) states that fresh seeds attract these animals with sweet, sticky liquid that is contained in the shell. Our observations showed that ants also spread dry seeds (Evstigneev et al., 2018b).
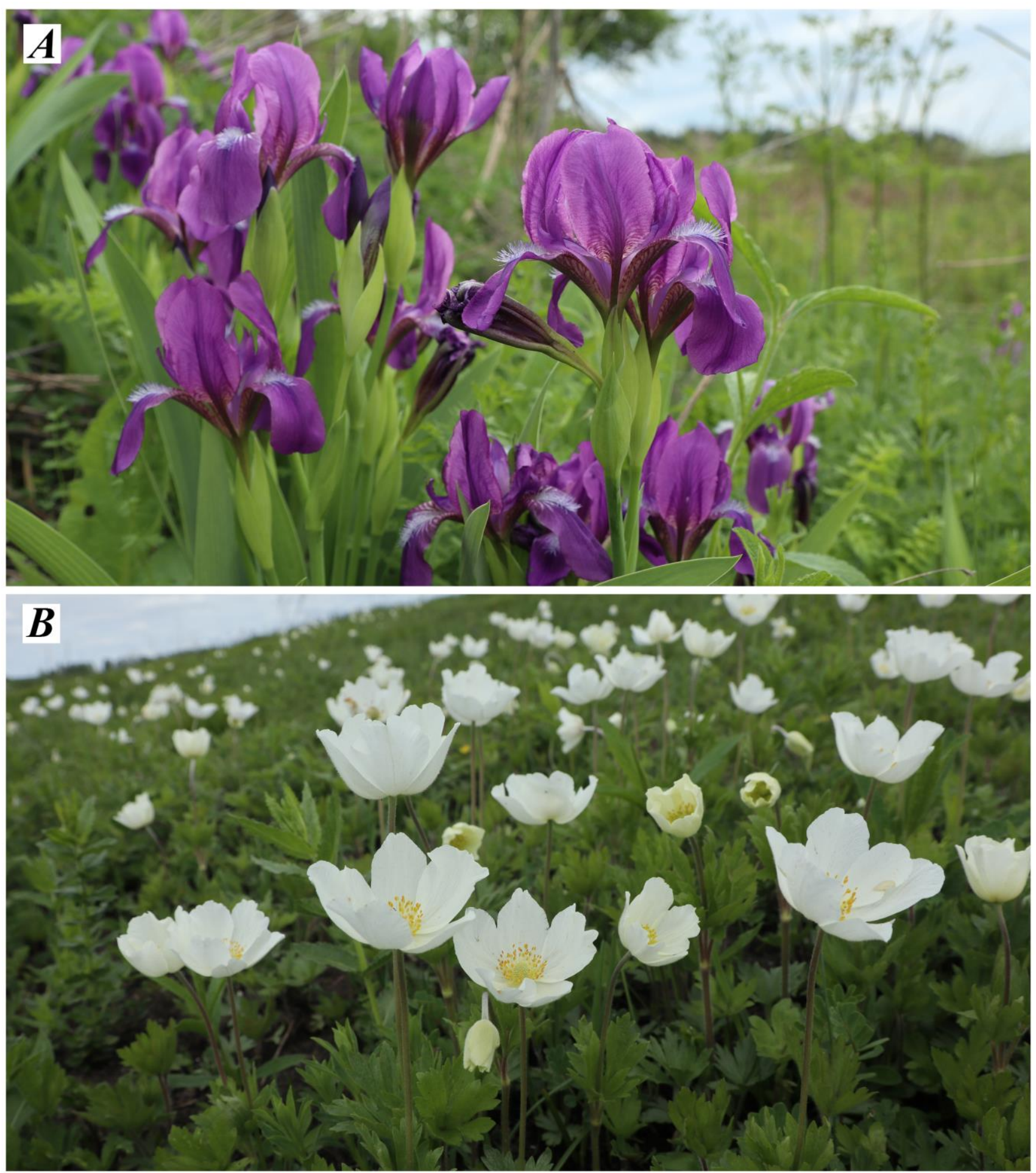

Figure 2. Model plants species in steppe meadows of the Melovitskie Slopes natural monument: $A-$ Iris aphylla, B - Anemone sylvestris. Photo by A.V. Gornov 

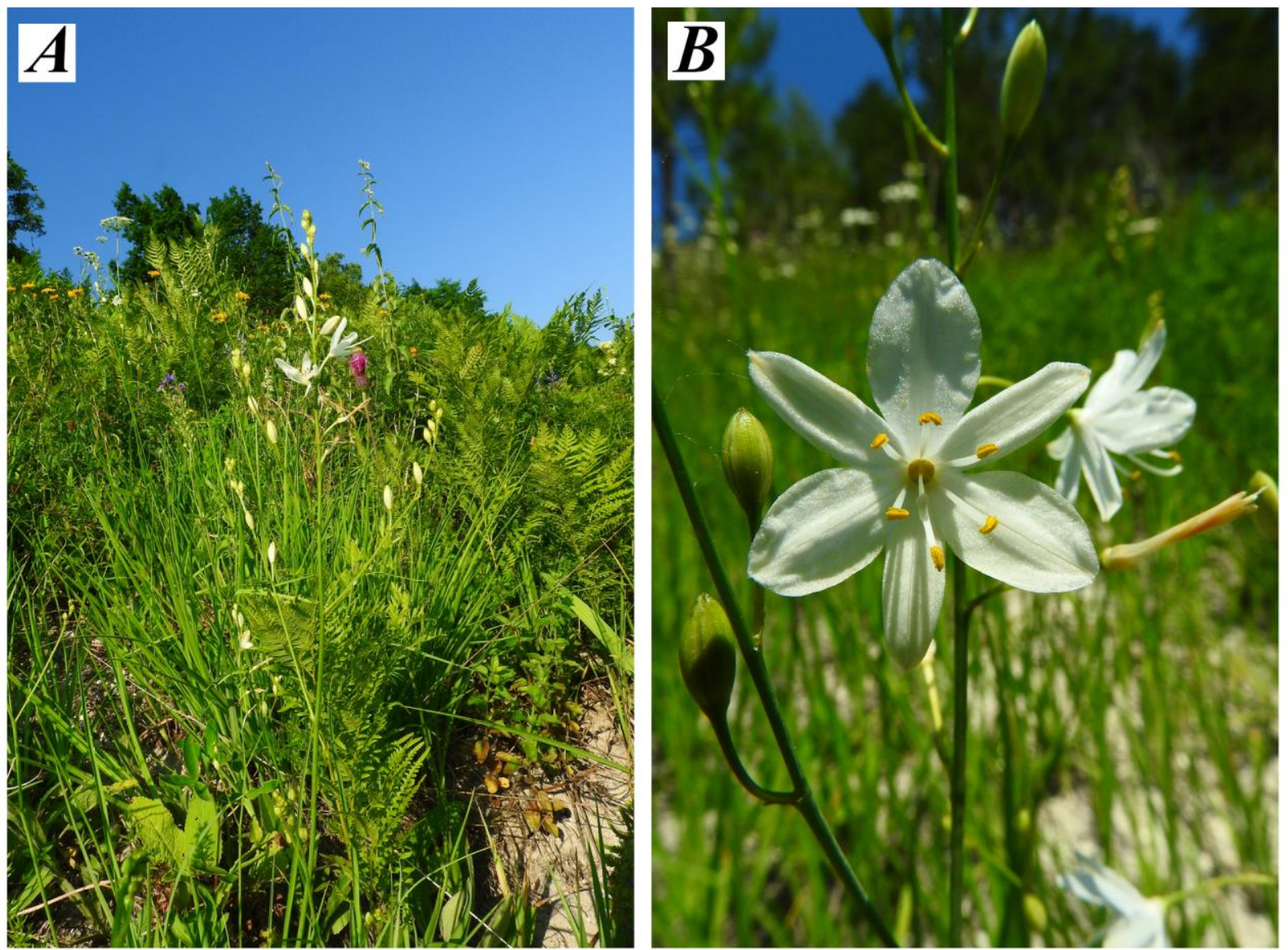

Figure 3. Model plants species in steppe meadows of the Melovitskie Slopes natural monument: $A, B$ - Anthericum ramosum. Photo by E.V. Ruchinskaya
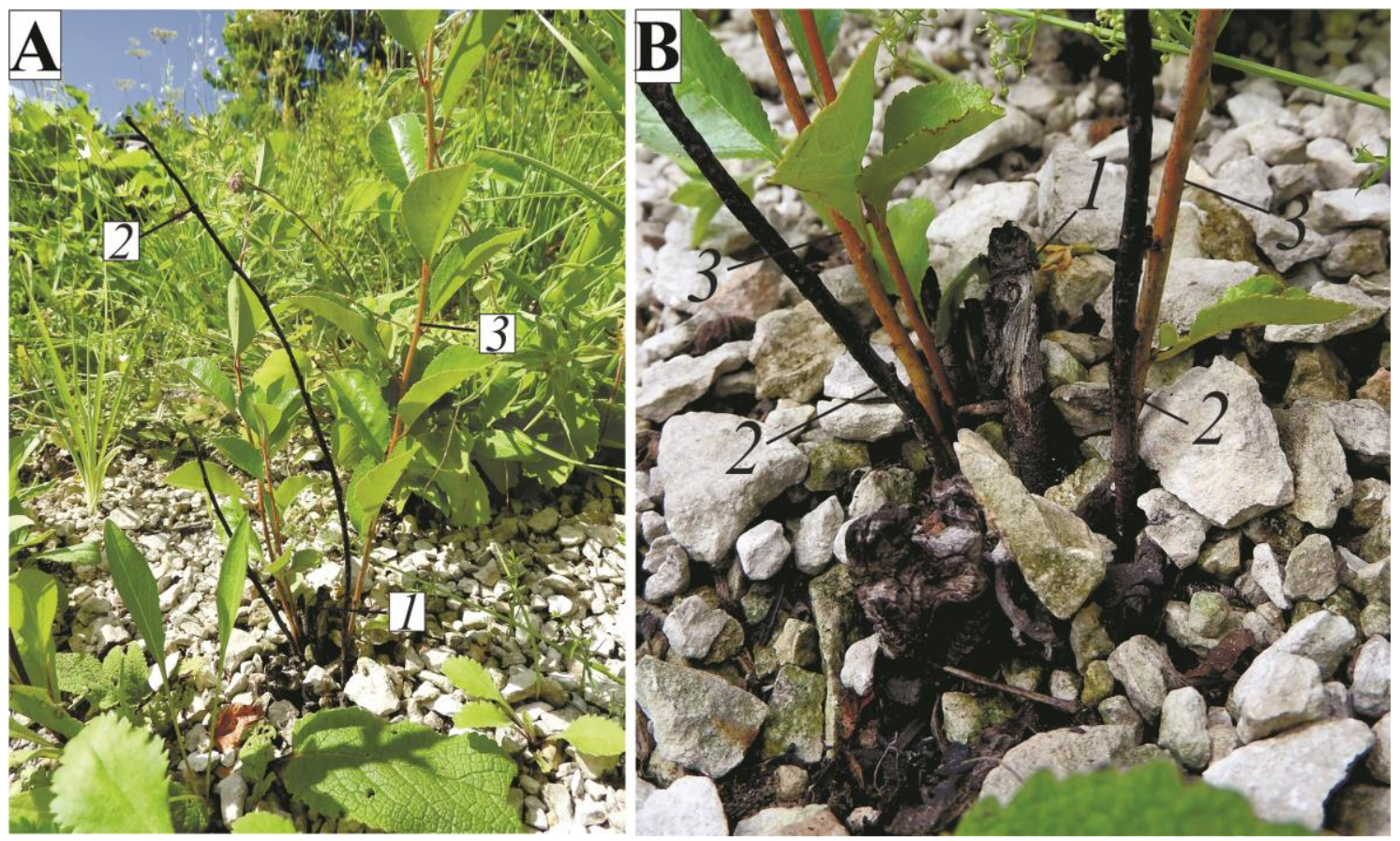

Figure 4. Coppice shoots of burnt sour cherry (Prunus cerasus).

A - general appearance of the shrub, B - base of the shrub. 1 - stump of a burnt perennial shoot, 2 - dead burnt biennial coppice shoot, 3 - live annual shoot that woke up from a dormant bud after a ground fire in the spring (from: Ruchinskaya, 2019) 

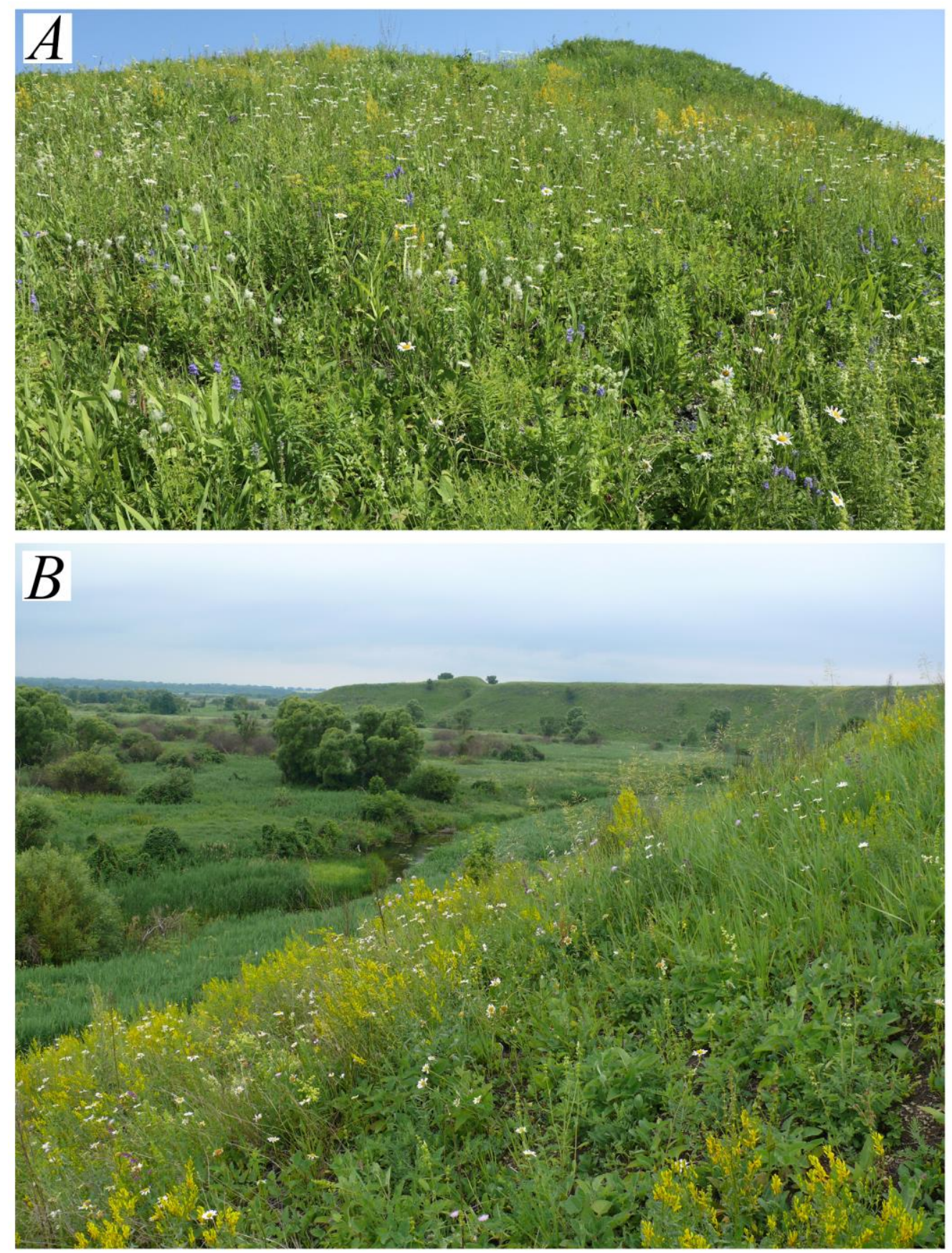

Figure 5. Polydominant steppe meadows in the territory of the Melovitskie Slopes natural monument. Photo by A.V. Gornov

Anthericum ramosum is a codominant species in the herb layer of steppe meadows. Population density of Anthericum ramosum is 56 plants per $1 \mathrm{~m}^{2}$. Ontogenetic spectrum is complete, left-hand type, single-peak with a maximum at $v$ and $g_{H}$ plants (Figure 6, 2a). The formation of the maximum at $v$ and $g_{H}$ plants is determined by the following: 1) short duration of $j$ and im states; 2) recruitment of plants resting from flowering; 3 ) recruitment of $v$ with plants of vegetative origin formed as a result of disintegration of $g_{2}$ plants.
Anemone sylvestris can be both an assectator and a codominant in the herb layer of steppe meadows. Population density of A. sylvestris is 75 plants per $1 \mathrm{~m}^{2}$. Ontogenetic spectrum is complete left-hand type with a maximum at im plants (Figure 6, 3a), the density of which is 27 trees per $1 \mathrm{~m}^{2}$. No A. sylvestris individuals of seed origin were found in the studied community. Therefore, the spectrum can be called vegetative and complete. High population density and the complete ontogenetic spectrum are determined by the 
biology of A. sylvestris. Large number of plants of the pregenerative state is due to the ability of $A$. sylvestris to vegetative reproduction with deep rejuvenation (Figure 8). Vegetative individuals develop from buds that appear on horizontal adventitious roots (Starostenkova, 1986; Barykina, Potapova, 1994). The beginning of the growth season in early spring, before the herb layer rises, contributes to the accumulation of a sufficient amount of macronutrients required for the formation of generative organs in plans. It is worth noting that the absence of seed individuals is evidence of adverse conditions for the coenopopulation. Apparently, this is due to the spread of fire on the slopes, which destroys young seed individuals of $A$. sylvestris.
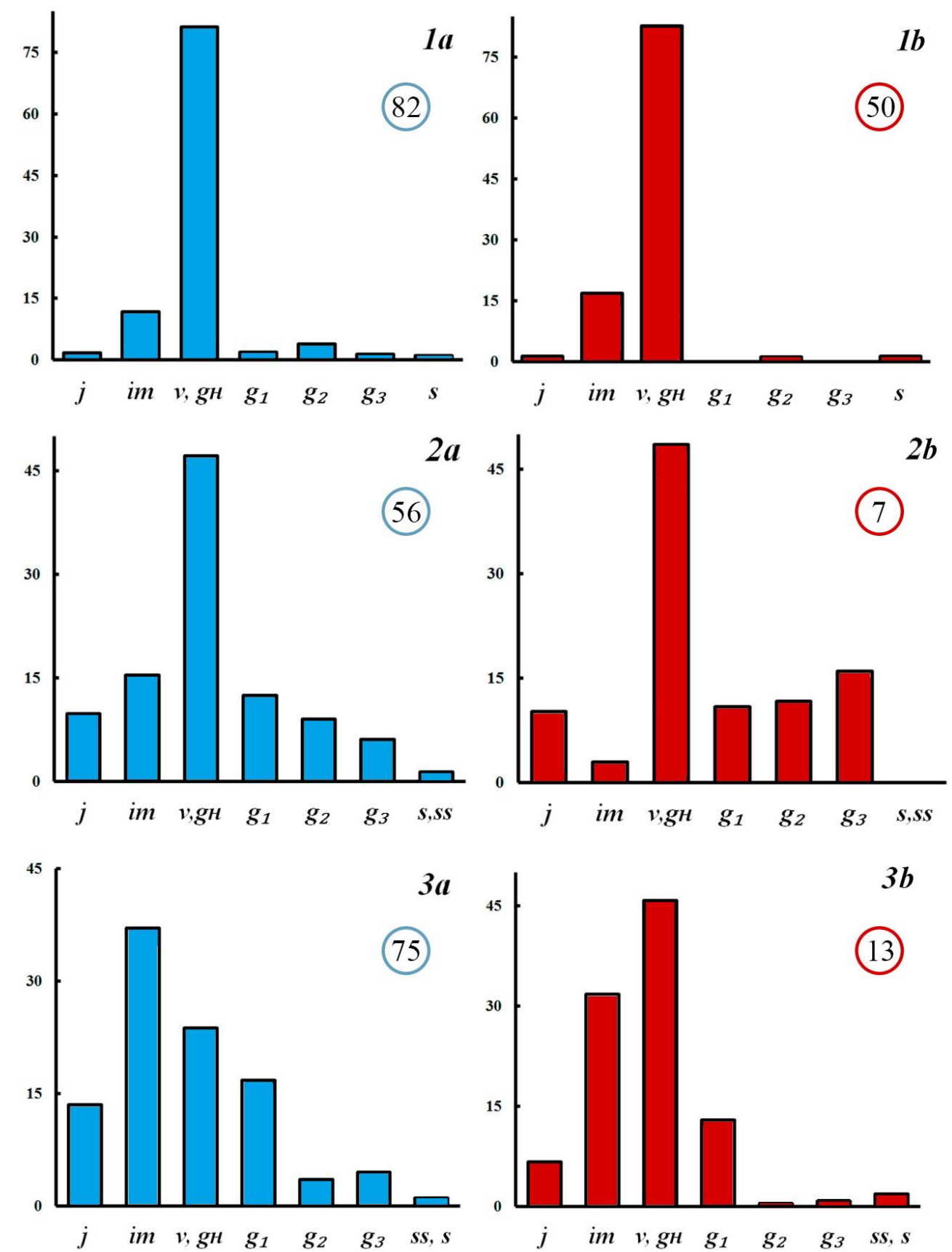

Figure 6. Ontogenetic spectrum of coenopopulations of model plant species in steppe meadows. 1 - Iris aphylla, 2 - Anthericum ramosum, 3 - Anemone sylvestris. The $\mathrm{X}$ axis shows ontogenetic states, and the $\mathrm{Y}$ axis - the proportion of individual plants, \%. Circled is population density (the number of plants per $1 \mathrm{~m}^{2}$ ) is shown. Communities: $a$-polydominant steppe meadows, $b$-polydominant steppe meadows with single generative trees. Ontogenetic states of trees: $j$-juvenile, $i m$-immature, $v$ - virginile, $g_{t}$ - temporarily not flowering generative plant, $g_{1}$-young generative, $g_{2}$ - mature generative, $g_{3}$ - old generative, $s s-$ subsenile, $s-$ senile 


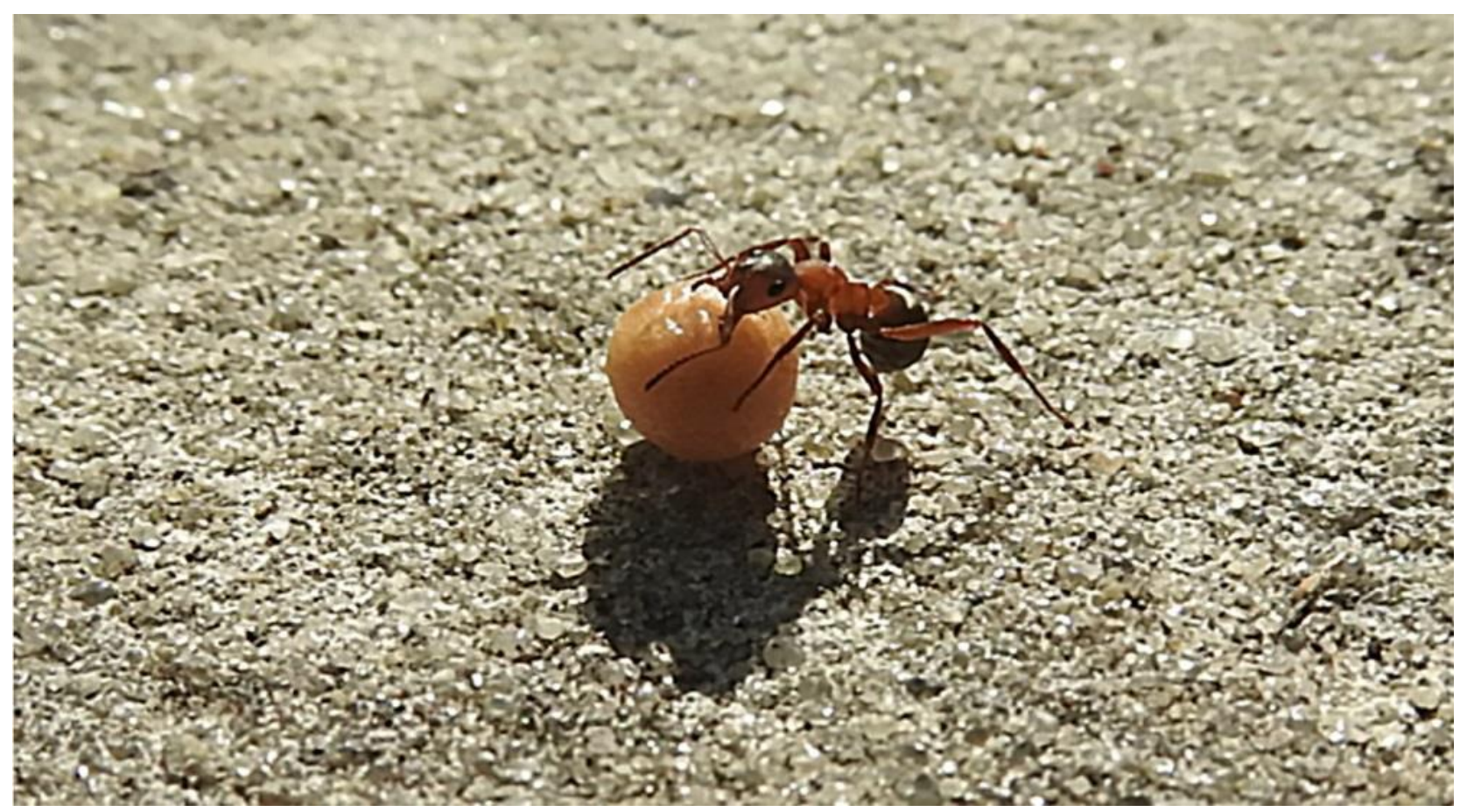

Figure 7. Dispersal of fresh Iris aphylla seeds by the red forest ant (Formica rufa).

Photo by E.V. Ruchinskaya
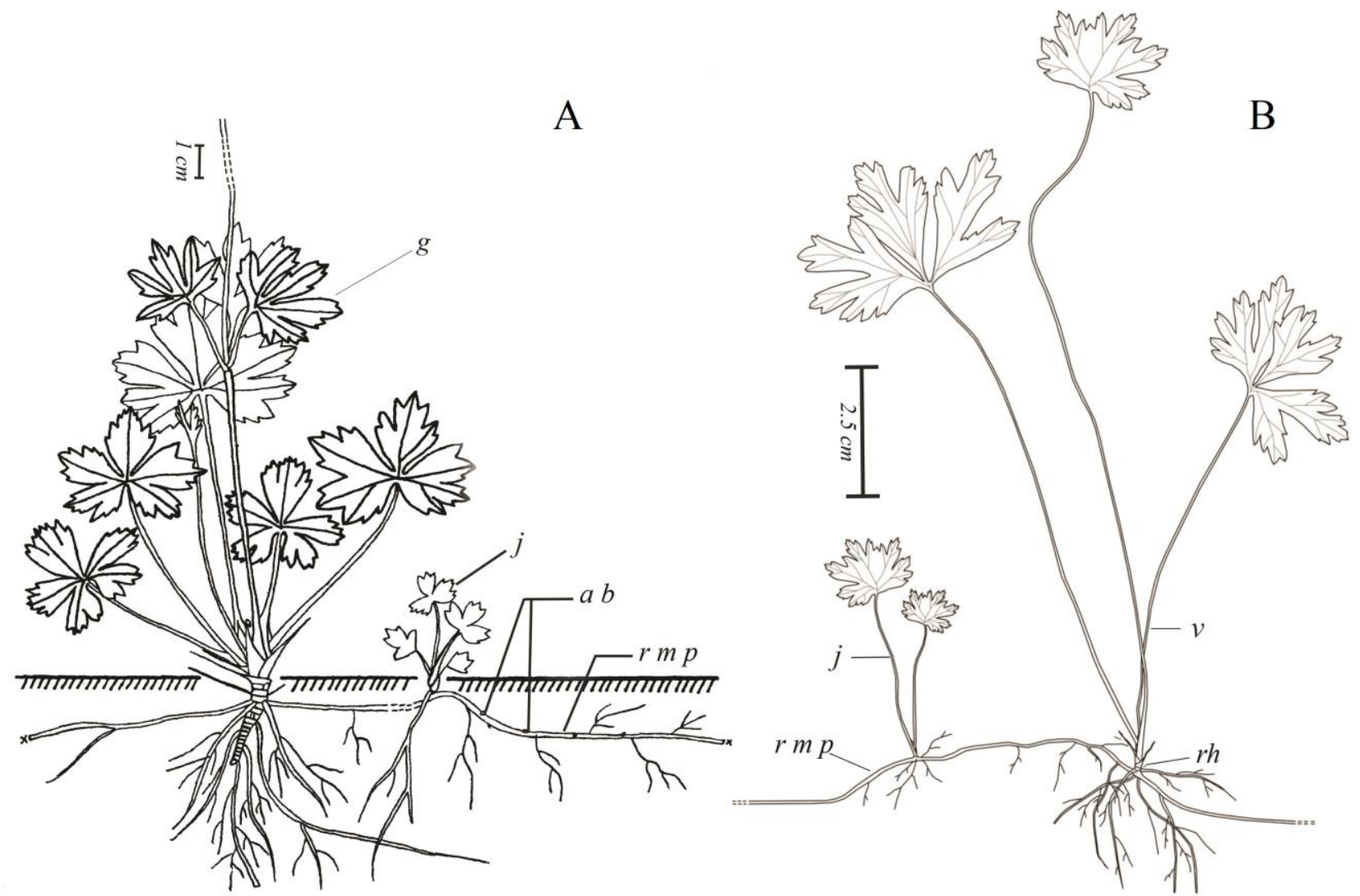

Figure 8. Vegetative renewal of Anemone sylvestris: A - generative individual with a root shoot and adventitious buds on the root (from: Barykina, Potapova, 1994, as supplemented), B - juvenile and virginile individuals of root shoot origin (from: Gornov et al., 2013). $j$ - juvenile individual, $g-$ generative individual, $v$ - virginal individual, $r m p$ - root of the parent plant, $r h$ - rhizome, $a b-$ adventitious bud 


\section{Polydominant steppe meadows with single} generative trees. On the slopes, there are single Quercus robur and Tilia cordata generative trees (Figure 9), which survived fire during their virginile stage. Mature oaks and linden trees are relatively resistant to ground fires: their renewal buds are located high, and the thick crust of the trunk protects the cambium (Serebrjakov, 1962). The steepness of the slope and the frequency of grass fires are similar to polydominant steppe meadows. Ordination of relevés divided polydominant steppe meadows and polydominant steppe meadows with single trees into distinct groups (Figure 10). The communities differ in the maximum values of species richness and species density (Table 1; Suppl. materials). High species diversity is due to several factors. First, in the past, the communities were not subjected to active grazing or haymaking, as they are also located on steep parts of the slopes. Second, single trees offer resting places and shelter for many animals, including birds. These are known to disperse seeds of meadow and forest plants (Manning et al., 2006; Prevedello et al., 2018). As a result, communities with freestanding trees have higher species richness than polydominant steppe meadows. The ecological-coenotic structure of the community is dominated by dry meadow and steppe plants. Under the crowns of single trees, the illuminance is reduced to $60 \%$ of the total. Shading reduces the cover of lightloving dry meadow and steppe plants. However, the number of species in this group increases. Allium oleraceum L., Artemisia absinthium L., Carex montana L., Cirsium decussatum Janka, Fallopia convolvulus (L.) Á. Löve, Filipendula vulgaris Moench, Hypericum perforatum L., Silene vulgaris (Moench) Garcke, S. viscaria (L.) Jess., Stachys officinalis (L.) Trevis., Veronica spuria L. etc. appear. In addition, the species composition of other ecological-coenotic groups also expands: Carex hirta L., $C$. lachenalii Schkuhr, Galeopsis bifida Boenn are found in the moist meadow group; the group of nemoral plants is supplemented by Euonymus europaeus L., Lathyrus niger (L.) Bernh. and Pyrus communis L., and the group of forest-edge nitrophilous group - by Galium aparine L. Apparently, this is due to the activity of animals, primarily birds, that use single trees like resting places and brought diaspores of these plants. It is known that birds actively disperse seeds of many plant species (Levina, 1957; Cramp, 1998, etc.). Thus, thanks to single trees, the polydominant composition of the community with maximum species diversity is maintained. However, shading has an adverse effect on the state of coenopopulations of model plant species.

Iris aphylla loses positions in the herb layer of polydominant steppe meadows with single generative trees. Population density is 50 plants per $1 \mathrm{~m}^{2}$. This is almost twice as low as in polydominant steppe meadows. A decrease in density is explained by the fact that due to the small amount of light, very few fruiting individuals able to produce viable seeds are formed in Iris aphylla. This leads to a four-fold drop in the number of young seed plants in the coenopopulation. Established plants feature an increased area of the leaf blade (Table 2). This adaptation allows the plants to get more of the scattered light. However, due to the lack of light, most individuals of Iris aphylla develop only to the $v$-ontogenetic state, and then die. As a result, an incomplete ontogenetic spectrum is formed with a maximum at $v$ plants (Figure $6,1 b$ ). If, over time, the number of trees on the slope increases, and they form a close-canopy area of the forest, the coenopopulation of Iris aphylla will disappear.

Anthericum ramosum shows low cover in the herb layer of polydominant steppe meadows with single generative trees. Under the tree canopy, population density of $A$. ramosum decreases sharply and only reaches 7 plants per $1 \mathrm{~m}^{2}$. This is eight times lower than in polydominant steppe meadows. Here, an unfinished left-hand type ontogenetic spectrum is formed with a maximum at $v$ and $g_{H}$ individuals (Figure 6, 2b). There are no ss or $s$ individuals in the coenopopulation, which is probably due to the death of plants already in the $g_{3}$ state. In addition, the decrease in the population density is explained by the fact that due to a small amount of light, the mortality of $j$ and $i m$ individuals increases. The group of $v$ and $g_{H}$ plants is replenished by 
single temporarily not flowering generative plants and particles formed as a result of disintegration of $g_{2}$ plants. For the same reason, the number of $g_{3}$ individuals, which are represented by branching and nonbranching particles, increases slightly.
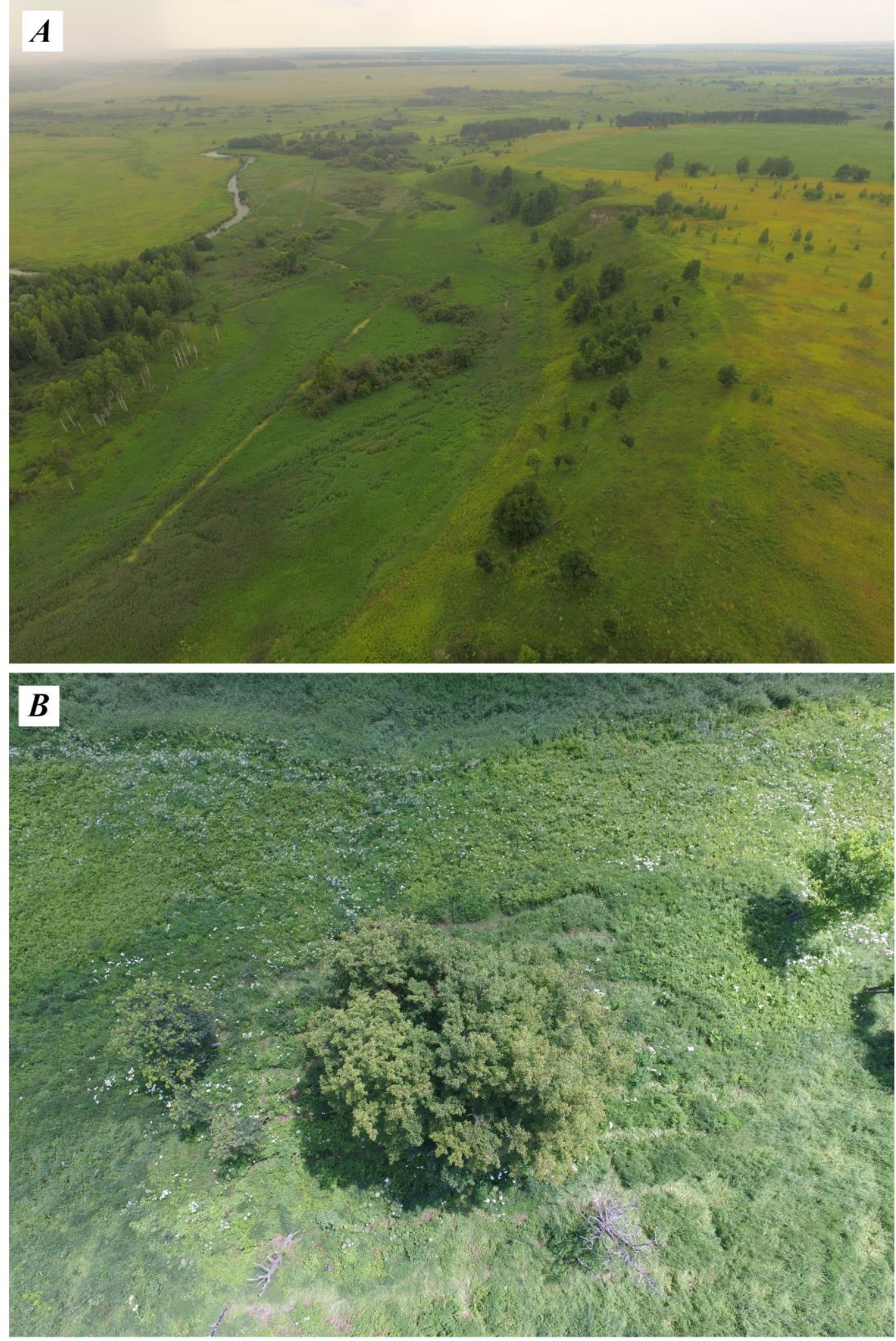

Figure 9. Polydominant steppe meadows with single trees: $A$ - general appearance of the slope, $B-$ crown of Tilia cordata from above. Photo by A.Yu. Sitnikov 
Table 2. Length and width of the leaves of Iris aphylla in the light (1) and in the shade (2)

\begin{tabular}{|l|c|c|c|c|c|c|c|c|}
\hline \multirow{2}{*}{ Measurement } & \multicolumn{2}{|c|}{$N$} & \multicolumn{2}{c|}{$M \pm m_{M}$} & \multicolumn{2}{c|}{$\sigma$} & \multicolumn{2}{c|}{$U$} \\
\cline { 2 - 9 } & 1 & 2 & 1 & 2 & 1 & 2 & 1 & 2 \\
\hline Leaf length, cm & 22 & 26 & $31.4 \pm 2.22$ & $60.6 \pm 1.70$ & 10.4 & 8.7 & $\mathbf{6}(p=0.000000)$ \\
\hline Leaf width, cm & 22 & 26 & $1.6 \pm 0.09$ & $2.3 \pm 0.08$ & 0.4 & 0.4 & $\mathbf{5 6}(p=0.000002)$ \\
\hline
\end{tabular}

Note. Communities: 1 - polydominant steppe meadows, 2 - polydominant steppe meadows with single generative trees. $N$ - number of measurements, $M$ - arithmetic mean, $m_{M}$ - error of the arithmetic mean, $\sigma$-standard deviation, $U$ - Mann-Whitney test values, $p$ - probability of error. Significant differences in the $U$ test are shown in bold.

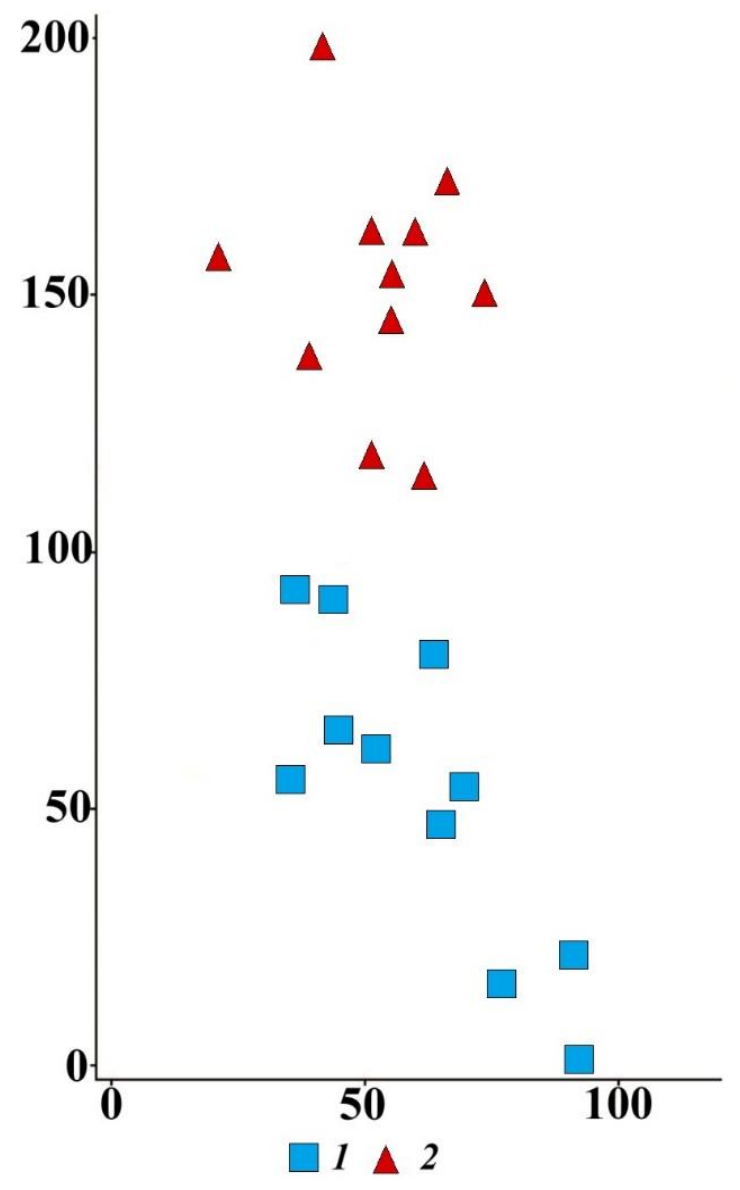

Figure 10. Results of DCA-ordination of relevés of steppe plant communities in the axes of the greatest variation in floristic composition. Communities: 1 -polydominant steppe meadows, 2 - polydominant steppe meadows with single generative trees

The projective cover of Anemone sylvestris is significantly less than in polydominant steppe meadows. Population density decreases six-fold - there are only 12 individuals per $1 \mathrm{~m}^{2}$. In the shade, most anemones do not form flower stalks. Therefore, the generative fraction is represented by single fruiting individuals with predominant $g_{l}$ plants. They are mainly found on the periphery of the crowns, where there is lateral illumination. As a result, the density of generative plants is ten times less than in the former community. This leads to a significant reduction in the replenishment of the coenopopulation with young plants, since the number of $g_{2}$ individuals that produce the largest number of root shoots decreases. Despite this, the ontogenetic spectrum of 
Anemone sylvestris is still complete and lefthand type. However, it shows an extremely low participation of generative individuals and a shift of the maximum to $v$ plants (Figure $6,3 b)$. The latter is due to the relatively long duration of the $v$-ontogenetic state and the insignificant replenishment of the coenopopulation by $j$ and $i m$ plants.

\section{CONCLUSION}

The maximum species diversity of polydominant steppe meadows is maintained on steep slopes unsuitable for ploughing up, where haymaking and grazing are difficult and fires are infrequent. This contributes to the formation of stable coenopopulations of model species. Their ontogenetic spectra belong to one type - complete left-hand type, with the maximum accounted for by young individuals. The mechanism of formation of this spectrum is species-specific. Thus, individuals of Iris aphylla and Anthericum ramosum are characterized by vegetative reproduction with shallow rejuvenation of particles and frequent breaks in flowering. In addition, the left-hand type structure is provided by high seed productivity, and in case of Anemone sylvestris - by active vegetative reproduction, when plants are deeply rejuvenated. Single trees (Quercus robur, Tilia cordata) have controversial influence on the vegetation of polydominant

\section{REFERENCES}

Averinova E.A., Ostepnjonnye opushechnye soobshhestva pamjatnikov prirody "Melovickie Sklony" i "Urochishhe Pechnoe" (Komarichskij rajon Brjanskoj oblasti) (Steppe marginal communities of natural monuments "Melovitsky Slopes" and "Urochishche Pechnoye" (Komarichsky district, Bryansk region)), Izuchenie $i$ ohrana biologicheskogo raznoobrazija Brjanskoj oblasti: materialy po vedeniju Krasnoj knigi Brjanskoj oblasti, Issue 5, Bryansk, 2010, pp. 21-26.

Barykina R.P., Potapova N.F., Biomorfologicheskij analiz vidov roda Anemone L. flory byvshego SSSR v hode ontogeneza (Biomorpological analysis of Anemone L. species during ontogenesis), Byulleten' Moskovskogo Obshchestva steppe meadows. On the one hand, with the introduction of trees, species diversity of communities increases. This is due to the fact that trees offer resting places and shelter for birds that spread plant diaspores. On the other hand, mature trees shade the herb cover. This leads to reduced cover and occurrence of steppe and dry meadow species, as well as affects their population structure. The number of individuals of all ontogenetic states is significantly reduced. The ontogenetic spectrum of Anemone sylvestris remains complete, whereas in Iris aphylla it becomes incomplete, and in Anthericum ramosum it becomes unfinished. If, over time, the number of trees on the slope increases, and they form a close-canopy area of the forest, coenopopulations of the model species will gradually disappear from the community.

\section{ACKNOWLEDGEMENTS}

The work was carried out as part of the state assignment of the CEPF RAS "Methodological approaches to the assessment of structural organization and functioning of forest ecosystems" (state registration number AAAA-A18-118052400130-7). The authors express their gratitude to Ye. A. Gavrilyuk, senior research officer of the CEPF RAS, for his help in drawing up the map.

Ispytatelei Prirody, Otdel Biologicheskii, 1994, Vol. 99, Issue 5, pp. 124-137. Bosek P.Z., O rasprostranenii stepnyh rastenij na territorii Brjanskoj oblasti (On the distribution of steppe plants in the Briansk district), Botanicheskij zhurnal, 1980, Vol. 65, No 6, pp. 829-836.

Bulohov A.D., Stepnye jelementy vo flore Brjanskoj oblasti (Steppe elements in the flora of Bryansk district), Botanicheskij zhurnal, 1977, No. 10, pp. 1505-1511.

Bulohov A.D., Travjanaja rastitel'nost' JugoZapadnogo Nechernozem'ja Rossii (Herbaceous vegetation of South-West Nonnlack Soil Zone of Russia), Bryansk, Izd-vo BGPU, 2001. 296 p.

Bulohov A.D., Velichkin Je.M., Opredelitel' rastenij Jugo-Zapadnogo Nechernozem'ja Rossii (Brjanskaja, Kaluzhskaja, Smolenskaja, Orlovskaja oblasti) (Keys to 
plants of the south-western Non-Black Earth region of Russia (Bryansk, Kaluga, Smolensk, Oryol regions), Bryansk: BGPU, 1997, 320 p.

$\begin{array}{ccr}\text { Cenopopuljacii } & \text { rastenij } & \text { (ocherki } \\ \text { populjacionnoj } & \text { biologii) } & \text { (Plant } \\ \text { coenopopulations } & \text { (essays of } & \text { plant }\end{array}$ population biology)), Moscow: Nauka, 1988, 184 p.

Chernova N.M., Bylova A.M., Obshhaja jekologija (General ecology), Moscow: Drofa, 2004, 416 p.

Cramp S., The complete birds of the Western Palearctic. UK, 1998. CD-ROM.

Dauber J., Wolters V., Microbial activity and functional diversity in the mounds of three different ant species, Soil Biol. Biochem, 2000, Vol. 32, Issue 1, pp. 93-99.

Dzhongman, R.G.G., Ter Braak S. Dzh. F., Van Tongeren O. F. R., Analiz dannyh v jekologii soobshhestv $i$ landshaftov (Data analysis in community and landscape ecology), Moscow: RASHN, 1999, 306 p.

Evstigneev O.I., Fedotov Ju.P., Gornov A.V., $\mathrm{K}$ flore pamjatnika prirody "Sevskie sklony" (Flora of the natural monement "Sevskie sklony"), Izuchenie $i$ ohrana biologicheskogo raznoobrazija Brjanskoj oblasti. Materialy po vedeniju Krasnoj knigi Brjanskoj oblasti, Bryansk, 2011, Issue 6, pp. 45-52.

Evstigneev O.I., Fedotov Ju.P., Kajgorodova E.Ju., Priroda Nerusso-Desnjanskogo poles'ja Brjanskoj oblasti. Redkie rastenija (The nature of the Nerusso-Desnyansky Polesye of the Bryansk region. Rare plants), Bryansk, 2000, 223 p.

Evstigneev O.I., Harlampieva M.V., Ontogenez i sostojanie populjacij Ligularia sibirica (Asteraceae) v nenarushennyh el'nikah na nizinnyh bolotah (Brjanskaja oblast') (Ontogeny and the population state of Ligularia sibirica (Asteraceae) in undisturbed swamped spruce forest in Bryansk region), Botanicheskij zhurnal, 2014, Vol. 99, No. 6, pp. 670-681.

Evstigneev O.I., Ruchinskaya E.V., Gornov A.V. Izmenenie ostepnennyh lugov V shirokolistvenno-lesnoj zone pod vozdejstviem palov i hozjajstvennoj dejatel'nosti (Brjanskaja obl.) (Changes of steppe meadows in the broad-leaved forest zone under impact of grass burning and economic activities (on the example of the nature monument "Melovitskie sklony", Bryansk region)), Botanicheskij zhurnal, 2018a, Vol. 103, No 12, pp. 1552-1564, doi: 10.1134/S0006813618120049.

Evstigneev O.I., Ruchinskaya E.V., Gornov A.V., Ontogenez i sostojanie cenopopuljacij Iris aphylla (Iridaceae) v Brjanskoj oblasti (Ontogeny and state of coenopopulation of Iris aphylla (Iridaceae) in the Bryansk region), Botanicheskij zhurnal, 2018b, Vol. 103, No. 2, pp. 207223, doi: 10.1134/S0006813618020047.

Gornov A.V., Panasenko N.N., Komarova M.V., Tarasenko A.V., Nekotorye osobennosti populjacionnoj biologii Anemone sylvestris L. (Ranunculaceae) v Brjanskoj oblasti (Some features of the population biology of Anemone sylvestris L. (Ranunculaceae) in the Bryansk region), Bjulleten' Brjanskogo otdelenija RBO, 2013, No. 1(1), pp. 25-30.

Gornova M.V., Evstigneev O.I., Ontogenez i sostojanie cenopopuljacij Melandrium dioicum (Cariophyllaceae) v vysokotravnyh el'nikah zony shirokolistvennyh lesov (Brjanskaja oblast') (Ontogeny and state of coenopopulations of Melandrium dioicum (Caryophyllaceae) in tall herb spruce forests in broadleaved forest zone (Bryansk region)), Botanicheskij zhurnal, 2016, Vol. 101, No. 8, pp. 896-910.

http://www.theplantlist.org/ $\quad(2020, \quad 15$ October)

Ipatov V.S., Fitogennye polja odinochnyh derev'ev nekotoryh porod $\mathrm{V}$ odnom jekotope (Phytogenic areas of single trees of some species in the same ecotope), Botanicheskij zhurnal, 2007, Vol. 92, No. 8, pp. 1186-1192.

Komarov N.F., Jetapy $i$ faktory jevoljucii rastitel'nogo pokrova chernozemnyh stepej (Stages and factors of the evolution of the vegetation cover of chernozem steppes), Moscow, 1951, 328 p.

Kostrakiewicz K., Wplyw zwierzat i drobnoustrojuw na populacje kosaccuw (Effect of animals and micro-organisms on Iris sp. populations), Chronmy Przyr. Ojczysta, 2004, Vol. 60, No 2, pp. 34-42. 
Krasnaja kniga Brjanskoj oblasti (Red data book of Bryansk region), Bryansk: RIO BGU, 2016. 432 p.

Krasnaja kniga Brjanskoj oblasti. Rastenija, griby (Red data book of Bryansk region. Plants, fungus), Bryansk: ZAO Izd-vo «Chitaj-gorod», 2004, 272 p.

Krasnaja kniga Kaluzhskoj oblasti (Red data book of Kaluga region), Kaluga, OOO "Vash dom", 2015, Vol. 1, 536 p.

Krasnaja kniga Kurskoj oblasti. Redkie $i$ ischezajushhie vidy rastenij $i$ gribov (Red data book of Kursk region. Rare and vanishing plant and fungi species), Tula, 2002, Vol. 2. 165 p.

Krasnaja kniga Rossijskoj Federacii (rastenija $i$ griby) (Red data book of Russian Federation (plants and fungus)), Moscow: Tovarishhestvo nauchnyh izdanij KMK, 2008, 855 p.

Levina R.E., Sposoby rasprostranenija plodov $i$ semjan (Dissemination ways of fruits and seeds), Moscow: Izd-vo MGU, 1957. 361 p.

Manning A., Fischer J., Lindenmayer D.B., Scattered trees are keystone structures Implications for conservation, Biol. cons, 2006, No. 132, pp. 311-321.

Mirkin B.M., Rozenberg G.S., Naumova L.G. Slovar' ponjatij $i$ terminov sovremennoj fitocenologii (Dictionary of concepts and terms of modern phytocenology), Moscow: "Nauka", 1989. 223 p.

Nikonov V.V., Lukina N.V., Smirnova E.V., Isaeva L.G., Vlijanie Picea obovata i Pinus sylvestris na pervichnuju produktivnost' nizhnih jarusov hvojnyh lesov Kol'skogo poluostrova (Influence of Picea obovata and Pinus sylvestris trees on the lower layer primary productivity in coniferous forests of the Kola peninsula), Botanicheskij zhurnal, 2002, Vol. 87, No. 8, pp. 107-119.

Odum Ju. Jekologija (Ecology), Vol. 2, Moscow: Mir, 1986. 376 p.

Orlova M.A., Lukina N.V., Smirnov V.E., Artemkina N.A., The influence of spruce on acidity and nutrient content in soils of northern taiga dwarf shrub-green moss spruce forests, Eurasian Soil Science, 2016, Vol. 49, No. 11, pp. 1276-1287.
Panasenko N.N., Evstigneev O.I., Fedotov Ju.P., Gornov A.V., K flore pamjatnika prirody «Markovskie gory» (Brjanskaja oblast') (Flora of the natural monument "Markovskie gory" (Bryansk region), Izuchenie $i$ ohrana biologicheskogo raznoobrazija Brjanskoj oblasti. Materialy po vedeniju Krasnoj knigi Brjanskoj oblasti, Issue 8, Bryansk, 2013, pp. 121131.

Panasenko N.N., Evstigneev O.I., Gornov A.V., Ruchinskaya E.V., $\mathrm{K}$ flore pamjatnika prirody "Melovickie sklony" (Brjanskaja oblast') (Flora of the Natural Monument "Melovitskie sklony" (Bryansk region)), Bjulleten' Brjanskogo otdelenija $R B O, 2015$, Vol. 2, No 6, pp. 17-25.

Prevedello J.A., Almeida-Gomes M., Lindenmayer D.B., The importance of scattered trees for biodiversity conservation: A global meta-analysis, Journal of Applied Ecology, 2018, No 55, pp. 205-214.

Prirodnoe rajonirovanie $i$ tipy sel'skohozjajstvennyh zemel' Brjanskoj oblasti (Natural zoning and types of agricultural lands), Bryansk, Priok. kn. izdvo. Brjan. otd-nie, 1975. $611 \mathrm{p}$.

Rabotnov T.A., Zhiznennyj cikl mnogoletnih travjanistyh rastenij $\mathrm{v}$ lugovyh cenozah (Life cycle of perennial herbaceous plants in meadow cenoses), Trudy BIN AN SSSR, Serija 3, Geobotanika, MoscowLeningrad, 1950, No. 6, pp. 7-204.

Rastitel'nost' Evropejskoj chasti SSSR (Vegetation of the European part of the USSR), Leningrad: Nauka, 1980, 420 p.

Ruchinskaya E.V., Strukturnoe $i$ vidovoe raznoobrazie rastitel'nosti ostepnennyh lugov $v$ zone shirokolistvennyh lesov (na primere pamjatnika prirody "Melovickie sklony”, Brjanskaja obl.), Diss. kand. biol. nauk (Structural and species diversity of vegetation of steppe meadows in the zone of deciduous forests (case study of the natural monument "Melovitsky slopes", Bryansk region) Candidate's biol. sci. thesis), Moscow: ILAN RAN, 2019, 197 p.

Samojlov Ju.I., Struktura fitogennogo polja na primere odinochnyh dubov Quercus robur (Fagaceae) (The structure of the phytogeneous field as exemplified by the 
single oak-trees Quercus robur (Fagaceae)), Botanicheskij zhurnal, 1983, Vol. 68, No. 8, pp. 1022-1034.

Semenishhenkov Ju.A., Kal'cefitnaja travjanaja rastitel'nost' v Brjanskoj oblasti: sintaksonomija, jekologija i voprosy ohrany (Calcephyte grassy vegetation in Bryansk region: syntaxonomy, ecology and protection), Vestnik VGU. Serija: Himija. Biologija. Farmacija, 2012, No. 1, pp. 149-163.

Semenishhenkov Ju.A., Ostepnennye luga pravoberezh'ja reki Desny - unikal'nye prirodnye kompleksy na granice botanikogeograficheskih podzon hvojnoshirokolistvennyh i shirokolistvennyh lesov (Steppe meadows on the right bank of the Desna River - unique natural complexes on the border of the botanicalgeographical subzones of coniferousdeciduous and deciduous forests), Problemy izuchenija $i$ vosstanovlenija landshaftov lesostepnoj zony. Tula, 2010, Issue 1, pp. 206-216.

Serebrjakov I.G., Jekologicheskaja morfologija rastenij (Ecological morphology of plants), Moscow: Vysshaja shkola, 1962, $378 \mathrm{p}$.

Skvorcov A.K., Kal'cefil'naja flora na juge Pogarskogo rajona Brjanskoj oblasti (Calciphilous flora in the Southern part of the Pogar district, Bryansk region, Byulleten' Moskovskogo Obshchestva Ispytatelei Prirody, Otdel Biologicheskii, 1982, Vol. 87, Issue 5, pp. 77-83.

Starostenkova M.M., Rod vetrenica (Genus Anemone), In: Biol. flora Moskovskoj oblasti (Biological flora of Moscow region), Moscow: Izdatel'stvo Moskovskogo universiteta, 1976, Isssue 3, pp. 119-138.

Uranov A.A., Fitogennoe pole (Phytogeneous field), In: Problemy sovremennoj botaniki (Challenges of modern botany). Vol. 1, Moscow-Leningrad: «Nauka», 1965, pp. 251-254.

Uranov A.A., Vozrastnoj spektr fitocenopopuljacij kak funkcija vremeni i jenergeticheskih volnovyh processov (Fitotsenopopulyatsy age spectrum as a function of time and energy of wave processes), Nauchnye doklady vysshej shkoly. Biologicheskie nauki, 1975, No. 2, pp. 7-34.

Zaugol'nova L.B., Struktura populjacij semennyh rastenij $i$ problemy ih monitoringa. Diss. dokt. biol. nauk (Seed plant population structure and challenges of their monitoring. Doctor's biol. sci. thesis), Saint-Petersburg, SPBGU, 1994a, $70 \mathrm{p}$.

Zaugol'nova L.B., Smirnova O.V., Vozrastnaja struktura cenopopuljacij mnogoletnih rastenij i ee dinamika (Age structure of cenopopulations of perennial plants and its dynamics), Zhurn. obshh. biol, 1978, Vol. 39, No. 6, pp. 849-858.

Zaugol'nova L.B., Smirnova O.V., Komarov A.S., Hanina L.G., Monitoring fitopopuljacij (Phytopopulation monitoring), Uspehi sovremennoj biologii, 1993, Vol. 113, No. 4, pp. 402-414.

Zelenaja kniga Brjanskoj oblasti (rastitel'nye soobshhestva, nuzhdajushhiesja v ohrane) (Green book of the Bryansk region (plant communities that are in need of protection: monography)), Bryansk: BGU, 2012, 144 p.

Zhukova L.A., Izmenenie vozrastnogo sostava populjacij lugovika dernistogo na Okskih lugah, Avtoref. diss. kand. biol. nauk (Changes in the age composition of populations of Deschampsia cespitosa in the Oka meadows. Abstract of Candidate's biol. sci. thesis), Moscow: MPGI im. V.I. Lenina, 1967, 19 p.

Zhuravleva E.N., Ipatov V.S., Lebedeva V.H., Tihodeeva M.Ju., Izmenenie rastitel'nosti na lugah pod vlijaniem sosny obyknovennoj (Pinus sylvestris L.) (Vegetation changes in meadows under the influence of Scots pine (Pinus sylvestris L.)), Vestnik Sankt-Peterburgskogo universiteta, 2012, Ser. 3, Issue 2, pp. 312.

Zrjanin V.A., Vlijanie murav'ev roda Lasius na pochvy lugovyh biogeocenozov (Effects of ants of the genus Lasius on soils of meadow biogeocenoses), Uspehi sovremennoj biologii, 2003, Vol. 123, No. 3, pp. 278-287.

Reviewer: candidate of Biological Sciences, Associate Professor Panasenko N.N. 
Supplementary materials

Species composition of the Melovitskie Slopes natural monument communities

\begin{tabular}{|c|c|c|c|}
\hline \multirow{3}{*}{ Plant name } & \multirow{2}{*}{\multicolumn{2}{|c|}{$\frac{\mathrm{PO}}{\text { Communities }}$}} & \multirow{3}{*}{ ECG } \\
\hline & & & \\
\hline & 1 & 2 & \\
\hline Achillea millefolium $\mathrm{L}$. & IV (+) & II (+) & D-Md \\
\hline Agrimonia eupatoria $\mathrm{L}$. & $\mathrm{V}(+)$ & $\operatorname{IV}(+)$ & $\mathrm{D}-\mathrm{Md}$ \\
\hline Ajuga genevensis L. & $\mathrm{I}(+)$ & $\mathrm{I}(+)$ & D-Md \\
\hline Allium oleraceum L. & - & $\mathrm{I}(+)$ & $\mathrm{D}-\mathrm{Md}$ \\
\hline Anemone sylvestris L. & $\mathrm{V}(1)$ & II (1) & $\mathrm{D}-\mathrm{Md}$ \\
\hline Anthericum ramosum $\mathrm{L}$. & $\mathrm{V}(1)$ & $\mathrm{V}(+)$ & $\mathrm{D}-\mathrm{Md}$ \\
\hline Anthyllis vulneraria $\mathrm{L}$. & $\mathrm{I}(+)$ & - & $\mathrm{D}-\mathrm{Md}$ \\
\hline Artemisia absinthium L. & - & $\mathrm{I}(+)$ & $\mathrm{D}-\mathrm{Md}$ \\
\hline Artemisia vulgaris L. & - & II (+) & D-Md \\
\hline Asparagus officinalis L. & $\mathrm{I}(+)$ & $\mathrm{V}(+)$ & D-Md \\
\hline Aster amellus L. & $\mathrm{V}(3)$ & II (1) & D-Md \\
\hline Astragalus cicer L. & IV $(+)$ & $\mathrm{V}(1)$ & D-Md \\
\hline Astragalus glycyphyllos L. & $\mathrm{I}(+)$ & $\mathrm{IV}(+)$ & D-Md \\
\hline Brachypodium pinnatum (L.) Beauv. & II (2) & $\mathrm{V}(3)$ & $\mathrm{Nm}-\mathrm{FE}$ \\
\hline Bromus inermis Leyss. & $\mathrm{V}(3)$ & $\mathrm{V}(4)$ & D-Md \\
\hline Calamagrostis epigejos (L.) Roth & IV $(+)$ & $\mathrm{V}(1)$ & D-Md \\
\hline Campanula bononiensis $\mathrm{L}$. & $\mathrm{V}(+)$ & $\mathrm{V}(+)$ & D-Md \\
\hline Campanula rapunculoides $\mathrm{L}$. & II $(+)$ & II $(+)$ & D-Md \\
\hline Campanula sibirica $\mathrm{L}$. & II $(+)$ & - & D-Md \\
\hline Carex hirta $\mathrm{L}$. & - & $\mathrm{I}(+)$ & M-Md \\
\hline Carex lachenalii Schkuhr & - & $\mathrm{IV}(+)$ & M-Md \\
\hline Carex montana $\mathrm{L}$. & - & $\mathrm{II}(+)$ & D-Md \\
\hline Carex praecox Schreb. & III $(+)$ & $\mathrm{IV}(+)$ & D-Md \\
\hline Centaurea jacea $\mathrm{L}$. & $\mathrm{III}(+)$ & - & D-Md \\
\hline Centaurea phrygia subsp. pseudophrygia (C.A. Mey.) Gugler & III (1) & II $(+)$ & D-Md \\
\hline Chamaecytisus ruthenicus (Fisch. ex Woloszcz.) Klaskova & $\mathrm{V}(+)$ & III $(+)$ & D-Md \\
\hline Cichorium intybus L. & $\mathrm{I}(+)$ & - & D-Md \\
\hline Cirsium decussatum Janka & - & $\mathrm{I}(+)$ & D-Md \\
\hline Cirsium pannonicum (L. fil.) Link & IV (1) & III $(+)$ & D-Md \\
\hline Convallaria majalis L. & IV (1) & IV (1) & $\mathrm{Nm}-\mathrm{Fo}$ \\
\hline Convolvulus arvensis $\mathrm{L}$. & III $(+)$ & $\mathrm{V}(+)$ & $\mathrm{D}-\mathrm{Md}$ \\
\hline Corylus avellana $\mathrm{L}$. & $\mathrm{IV}(+)$ & $\mathrm{V}(+)$ & $\mathrm{Nm}-\mathrm{Fo}$ \\
\hline Dactylis glomerata L. & III $(+)$ & $\mathrm{V}(+)$ & M-Md \\
\hline Elymus repens (L.) Gould & II $(+)$ & II $(+)$ & D-Md \\
\hline Equisetum arvense L. & - & $\mathrm{I}(+)$ & D-Md \\
\hline Erigeron annuus (L.) Desf. & - & $\mathrm{I}(+)$ & D-Md \\
\hline Euonymus europaeus L. & - & III $(+)$ & $\mathrm{Nm}-\mathrm{Fo}$ \\
\hline Euphorbia esula L. & II $(+)$ & $\mathrm{I}(+)$ & D-Md \\
\hline Euphorbia semivillosa (Prokh.) Krylov & $\mathrm{V}(2)$ & $\mathrm{V}(+)$ & D-Md \\
\hline Fallopia convolvulus (L.) Á. Löve & - & $\mathrm{I}(+)$ & D-Md \\
\hline Festuca pratensis Huds. & II $(+)$ & - & D-Md \\
\hline Filipendula vulgaris Moench & - & $\mathrm{IV}(+)$ & $\mathrm{D}-\mathrm{Md}$ \\
\hline
\end{tabular}




\begin{tabular}{|c|c|c|c|}
\hline \multirow{3}{*}{ Plant name } & \multirow{2}{*}{\multicolumn{2}{|c|}{$\begin{array}{c}\mathrm{PO} \\
\text { Communities }\end{array}$}} & \multirow{3}{*}{ ECG } \\
\hline & & & \\
\hline & 1 & 2 & \\
\hline Fragaria viridis Weston & III $(+)$ & III $(+)$ & D-Md \\
\hline Frangula alnus Mill. & $\mathrm{IV}(+)$ & II $(+)$ & $\mathrm{Br}-\mathrm{Fo}$ \\
\hline Galatella linosyris (L.) Rchb.f. & II $(+)$ & II $(+)$ & D-Md \\
\hline Galeopsis bifida Boenn. & - & III $(+)$ & M-Md \\
\hline Galium aparine $\mathrm{L}$. & - & IV $(+)$ & $\mathrm{Nt}-\mathrm{FE}$ \\
\hline Galium boreale L. & $\mathrm{V}(+)$ & $\mathrm{V}(1)$ & D-Md \\
\hline Galium mollugo L. & $\mathrm{V}(1)$ & $\mathrm{V}(1)$ & M-Md \\
\hline Galium tinctorium $\mathrm{L}$. & $\mathrm{V}(1)$ & $\mathrm{V}(+)$ & D-Md \\
\hline Galium verum $\mathrm{L}$. & $\mathrm{V}(+)$ & $\mathrm{V}(+)$ & D-Md \\
\hline Genista tinctoria $\mathrm{L}$. & $\mathrm{IV}(+)$ & $\mathrm{I}(+)$ & D-Md \\
\hline Geranium sanguineum L. & $\mathrm{IV}(+)$ & $\mathrm{IV}(+)$ & D-Md \\
\hline Hypericum perforatum $\mathrm{L}$. & $\mathrm{I}(+)$ & III $(+)$ & D-Md \\
\hline Inula hirta $\mathrm{L}$. & II (1) & IV $(+)$ & D-Md \\
\hline Inula salicina $\mathrm{L}$. & $\mathrm{V}(1)$ & $\mathrm{V}(+)$ & D-Md \\
\hline Iris aphylla $\mathrm{L}$. & $\mathrm{V}(3)$ & $\mathrm{V}(2)$ & D-Md \\
\hline Knautia arvensis (L.) Coult. & III $(+)$ & $\mathrm{V}(+)$ & D-Md \\
\hline Lactuca serriola $\mathrm{L}$. & - & $\mathrm{I}(+)$ & D-Md \\
\hline Laserpitium latifolium $\mathrm{L}$. & IV (1) & $\mathrm{V}(2)$ & $\mathrm{Nm}-\mathrm{FE}$ \\
\hline Lathyrus niger (L.) Bernh. & - & $\mathrm{V}(1)$ & $\mathrm{Nm}-\mathrm{Fo}_{\mathrm{O}}$ \\
\hline Lathyrus pisiformis L. & $I(+)$ & - & $\mathrm{Nm}-\mathrm{FE}$ \\
\hline Lathyrus sylvestris L. & II $(+)$ & IV (1) & $\mathrm{Nm}-\mathrm{FE}$ \\
\hline Lavatera thuringiaca $\mathrm{L}$. & $\mathrm{I}(+)$ & $\mathrm{I}(+)$ & D-Md \\
\hline Leucanthemum vulgare (Vaill.) Lam. & IV (1) & $\mathrm{I}(+)$ & D-Md \\
\hline Linum flavum L. & $\mathrm{IV}(+)$ & $\mathrm{I}(+)$ & D-Md \\
\hline Lithospermum officinale L. & $\mathrm{IV}(+)$ & $\mathrm{IV}(+)$ & D-Md \\
\hline Medicago falcata $\mathrm{L}$. & $\mathrm{I}(+)$ & $\mathrm{V}(+)$ & D-Md \\
\hline Myosotis ramosissima Rochel & - & $\mathrm{I}(+)$ & D-Md \\
\hline Nepeta nuda L. & I (1) & IV (2) & D-Md \\
\hline Origanum vulgare L. & IV (1) & $\mathrm{V}(1)$ & D-Md \\
\hline Peucedanum alsaticum $\mathrm{L}$. & $\mathrm{V}(1)$ & $\mathrm{V}(+)$ & D-Md \\
\hline Peucedanum cervaria (L.) Cusson ex Lapeyr. & IV (1) & $\mathrm{V}(1)$ & $\mathrm{Nm}-\mathrm{FE}$ \\
\hline Peucedanum oreoselinum (L.) Moench & $\mathrm{I}(+)$ & - & D-Md \\
\hline Phlomoides tuberosa (L.) Moench & II $(+)$ & II (1) & D-Md \\
\hline $\begin{array}{l}\text { Pilosella piloselloides subsp. bauhinii (Schult.) S.Bräut. \& } \\
\text { Greuter }\end{array}$ & $\mathrm{I}(+)$ & - & D-Md \\
\hline Plantago lanceolata $\mathrm{L}$. & $\mathrm{I}(+)$ & - & D-Md \\
\hline Plantago media L. & $I(+)$ & - & D-Md \\
\hline Poa angustifolia $\mathrm{L}$. & $\mathrm{V}(1)$ & $\mathrm{V}(1)$ & D-Md \\
\hline Poa trivialis $\mathrm{L}$. & - & $\mathrm{IV}(+)$ & M-Md \\
\hline Podospermum purpureum (L.) W.D.J. Koch \& Ziz & $\mathrm{I}(+)$ & - & D-Md \\
\hline Polygala comosa Schkuhr & III $(+)$ & - & D-Md \\
\hline Polygonatum odoratum (Mill.) Druce & III $(+)$ & II $(+)$ & D-Md \\
\hline Prunus cerasus L. & IV (1) & III $(+)$ & D-Md \\
\hline Pteridium aquilinum (L.) Kuhn & IV (2) & $\mathrm{V}(2)$ & $\mathrm{Pn}$ \\
\hline Pyrethrum corymbosum (L.) Scop. & $\mathrm{V}(1)$ & $\mathrm{V}(1)$ & $\mathrm{Nm}-\mathrm{FE}$ \\
\hline
\end{tabular}




\begin{tabular}{|c|c|c|c|}
\hline \multirow{3}{*}{ Plant name } & & & \multirow{3}{*}{ ECG } \\
\hline & \multicolumn{2}{|c|}{ Communities } & \\
\hline & 1 & 2 & \\
\hline Pyrus communis $\mathrm{L}$. & - & $\mathrm{I}(+)$ & $\mathrm{Nm}-\mathrm{Fo}$ \\
\hline Quercus robur L. & $\mathrm{I}(+)$ & $\mathrm{V}(+)$ & $\mathrm{Nm}-\mathrm{Fo}$ \\
\hline Ranunculus polyanthemos $\mathrm{L}$. & IV $(+)$ & $\mathrm{I}(+)$ & $\mathrm{D}-\mathrm{Md}$ \\
\hline Rubus caesius $\mathrm{L}$. & $\mathrm{II}(+)$ & III (1) & Nt-FE \\
\hline Salvia pratensis L. & $\mathrm{V}(3)$ & $\mathrm{V}(1)$ & D-Md \\
\hline Salvia verticillata $\mathrm{L}$. & $\mathrm{II}(+)$ & $\mathrm{I}(+)$ & D-Md \\
\hline Securigera varia (L.) Lassen & IV (1) & $\mathrm{V}(1)$ & D-Md \\
\hline Sedum maximum (L.) Suter & $\mathrm{I}(+)$ & - & D-Md \\
\hline Sedum telephium $\mathrm{L}$. & $\mathrm{I}(+)$ & - & D-Md \\
\hline Serratula tinctoria $\mathrm{L}$. & - & $\mathrm{I}(+)$ & $\mathrm{Nm}-\mathrm{FE}$ \\
\hline Seseli libanotis (L.) W.D.J. Koch & I (2) & III (+) & D-Md \\
\hline Silene latifolia Poir. & $\mathrm{I}(+)$ & III $(+)$ & D-Md \\
\hline Silene nutans L. & $\mathrm{I}(+)$ & $\mathrm{I}(+)$ & D-Md \\
\hline Silene viscaria (L.) Jess. & - & $\mathrm{I}(+)$ & D-Md \\
\hline Silene vulgaris (Moench) Garcke & - & $\mathrm{I}(+)$ & D-Md \\
\hline Solidago virgaurea $\mathrm{L}$. & $\mathrm{I}(+)$ & III (+) & Pn \\
\hline Stachys officinalis (L.) Trevis. & - & $\mathrm{V}(+)$ & D-Md \\
\hline Stachys recta $\mathrm{L}$. & V (3) & $\mathrm{V}(1)$ & D-Md \\
\hline Succisa pratensis Moench & $\mathrm{I}(+)$ & - & M-Md \\
\hline Taraxacum officinale Wigg. & $\mathrm{II}(+)$ & $\mathrm{I}(+)$ & D-Md \\
\hline Thalictrum lucidum $\mathrm{L}$. & III $(+)$ & - & M-Md \\
\hline Thalictrum minus L. & III (1) & $\mathrm{III}(+)$ & D-Md \\
\hline Tilia cordata Mill. & - & IV $(+)$ & $\mathrm{Nm}-\mathrm{Fo}$ \\
\hline Tragopogon dubius Scop. & $\mathrm{I}(+)$ & - & D-Md \\
\hline Trifolium alpestre $\mathrm{L}$. & $\mathrm{V}(1)$ & $\mathrm{V}(1)$ & D-Md \\
\hline Trifolium montanum $\mathrm{L}$. & $\mathrm{V}(+)$ & II (+) & D-Md \\
\hline Valeriana officinalis $\mathrm{L}$. & III $(+)$ & II $(+)$ & $\mathrm{Nt}-\mathrm{FE}$ \\
\hline Verbascum lychnitis L. & II $(+)$ & $\mathrm{I}(+)$ & D-Md \\
\hline Verbascum nigrum $\mathrm{L}$. & $\mathrm{V}(+)$ & $\mathrm{IV}(+)$ & D-Md \\
\hline Veronica austriaca subsp. teucrium (L.) D.A. Webb & $\mathrm{V}(1)$ & $\mathrm{V}(1)$ & D-Md \\
\hline Veronica chamaedrys L. & - & $\mathrm{I}(+)$ & D-Md \\
\hline Veronica spuria $\mathrm{L}$. & - & $\mathrm{I}(+)$ & D-Md \\
\hline Vicia tenuifolia Roth & $\mathrm{V}(2)$ & $\mathrm{V}(1)$ & D-Md \\
\hline Vicia tetrasperma (L.) Schreb. & - & $\mathrm{I}(+)$ & M-Md \\
\hline Vincetoxicum hirundinaria Medik. & $\mathrm{V}(1)$ & $\mathrm{V}(+)$ & D-Md \\
\hline Viola canina $\mathrm{L}$. & $\mathrm{I}(+)$ & - & M-Md \\
\hline Viola collina Besser. & III $(+)$ & IV $(+)$ & $\mathrm{Pn}$ \\
\hline Viola hirta L. & $\operatorname{IV}(+)$ & $\mathrm{V}(+)$ & D-Md \\
\hline Viola mirabilis L. & $\mathrm{I}(+)$ & III $(+)$ & $\mathrm{Nm}-\mathrm{Fo}$ \\
\hline Number of species & 98 & 107 & \\
\hline
\end{tabular}

Note. Communities: 1 - polydominant steppe meadows, 2 - polydominant steppe meadows with single generative trees PO - average occurrence points, Arabic numerals and «+»- points of cover-abundance scale proposed by J. BraunBlanquet. ECG - ecological-coenotic groups: D-Md - dry meadow, M-Md - moist meadow, Pn - piny (boreal forestedge), Nm-FE - nemoral forest edge, Nm-Fo - nemoral forest, Nt-FE - nitrophilous forest-edge, Br-Fo - boreal forest. 